\title{
Stomal varices: a cause for intermittent haematuria post-radical cystectomy
}

\author{
Su-Min Lee, Kishoj Yogan, Thomas Carr
}

Department of Urology, Southend University Hospital, Westcliff-on-Sea, Essex, UK

\section{Correspondence to}

Su-Min Lee,

smlee84@gmail.com

Accepted 25 December 2015

CrossMark

To cite: Lee S-M, Yogan $\mathrm{K}$, Carr T. BMJ Case Rep

Published online: [please include Day Month Year] doi:10.1136/bcr-2015214082

\section{DESCRIPTION}

A 74-year-old man presented to hospital with intermittent episodes of frank, painless haematuria, 2 years post-radical cystectomy with ileal conduit. Stoma examination revealed dilated stomal varices and peri-stomal ecchymoses (figure 1). An abdominal CT scan confirmed a thickened distal ileal conduit and a cirrhotic liver with dilated portal venous system. A diagnosis of stomal varices secondary to portal hypertension and liver cirrhosis was made. The patient underwent suture ligation of the bleeding varices.

Haematuria from ileal conduits may arise from a variety of conditions, including infections, calculi and recurrent disease, and it is vital to exclude these common conditions. Stomal varices occur at the mucocutaneous junction and are characterised by a surrounding purplish hue. ${ }^{1}$ They are an example of ectopic varices, that is, dilated portosystemic collateral veins in unusual sites. Ectopic varices account for approximately $1-5 \%$ of all variceal bleeding and only rarely have they been reported in ileal conduit stomas. ${ }^{2}$ Bleeding due to stomal varices can lead to significant haematuria and blood loss, and early recognition is vital.

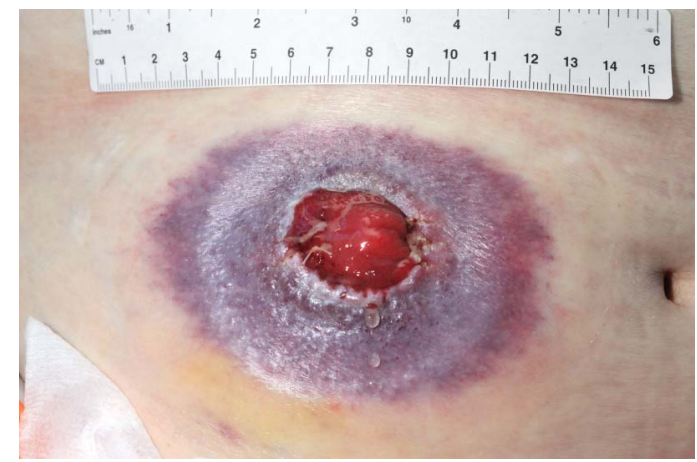

Figure 1 lleal conduit stoma with suture ligated varices at the mucocutaneous junction. Peri-stomal purplish discolouration is noted, characteristic of stomal varices.
Management is challenging; local treatment, including pressure, cautery, sclerotherapy and suture ligation, may be effective in the short term. ${ }^{1}$ However, if these fail to halt recurrent bleeding, management of underlying liver disease and portal hypertension is required. $\beta$-Blockers, somatostatin analogues and vasopressin have been used to reduce portal hypertension, but some patients require surgical or radiologically guided shunts to decompress the portal venous system. ${ }^{3}$

Surgeons should consider this unusual cause in their differentials for haematuria in the radical cystectomy patient.

\section{Learning points}

Stomal varices are a rare case of haematuria from ileal conduits and may lead to significant blood loss.

- Stomal varices are characterised by purplish peri-stomal discolouration.

- Local management may be employed; however, recurrent bleeding requires management of underlying portal hypertension with medications or surgical shunting.

Contributors S-ML drafted the manuscript. KY critically revised the manuscript and obtained the image. TC critically revised the manuscript and had final approval.

Competing interests None declared.

Patient consent Obtained.

Provenance and peer review Not commissioned; externally peer reviewed.

\section{REFERENCES}

1 Sarin SK, Kumar CKN. Ectopic varices. Clin Liver Dis 2012;1:168-72.

2 Lebrec D, Benhamou JP. Ectopic varices in portal hypertension. Clin Gastroenterol 1985;14:105-21.

3 Bloom S, Kemp W, Lubel J. Portal hypertension: pathophysiology, diagnosis and management. Intern Med J 2015;45:16-26.

Copyright 2016 BMJ Publishing Group. All rights reserved. For permission to reuse any of this content visit

http://group.bmj.com/group/rights-licensing/permissions.

BMJ Case Report Fellows may re-use this article for personal use and teaching without any further permission.

Become a Fellow of BMJ Case Reports today and you can:

- Submit as many cases as you like

- Enjoy fast sympathetic peer review and rapid publication of accepted articles

- Access all the published articles

- Re-use any of the published material for personal use and teaching without further permission

For information on Institutional Fellowships contact consortiasales@bmjgroup.com

Visit casereports.bmj.com for more articles like this and to become a Fellow 